\title{
Lactobacillus fornicalis sp. nov., isolated from the posterior fornix of the human vagina
}

\author{
L. M. T. Dicks, ${ }^{1}$ M. Silvester, ${ }^{1}$ P. A. Lawson ${ }^{2}$ and M. D. Collins ${ }^{2}$ \\ Author for correspondence: L. M. T. Dicks. Tel: +27 21 8084536. Fax: +27 218083611. \\ e-mail:1mtd@maties.sun.ac.za
}

\footnotetext{
1 Department of Microbiology, University of Stellenbosch, Stellenbosch 7600 , South Africa

2 Department of Food Science and Technology, University of Reading, Reading RG6 6AP, UK
}

\begin{abstract}
Twelve strains isolated from the posterior fornix fluid of the human vagina were identified as Lactobacillus johnsonii, Lactobacillus acidophilus, Lactobacillus gallinarum and Lactobacillus crispatus based on numerical analyses of total soluble cell protein profiles and randomly amplified polymorphic DNA (RAPD)-PCR banding patterns. Five strains grouped with the type strains of Lactobacillus gasseri (DSM 20077') and Lactobacillus jensenii (DSM 20557') at $r \geq 0.83$ in one protein profile cluster, well separated from the other species included in this study. However, numerical analysis of the RAPDPCR banding patterns of representative strains selected from the $L$. gasseri- $L$. jensenii protein cluster clearly indicated that they belong to two different species. Four strains (TV 1010, TG 1013, TV $1018^{\top}$ and TV 1045) grouped into another well separated protein profile cluster at $r \geq 0.87$. Strains selected from this cluster displayed very similar RAPD-PCR banding patterns and clustered at $R^{2} \geq 0.78$, separate from the other strains examined. Sequencing of the $16 \mathrm{~S}$ rRNA of two representative strains, TV $1018^{\top}$ and TG 1013, of this group indicated that it represents a new member of rRNA group I Lactobacillus, which includes Lactobacillus delbrueckii, the type of the genus, and close relatives Lactobacillus acetotolerans, Lactobacillus kefiranofaciens, Lactobacillus iners, L. jensenif, L. crispatus, L. acidophilus, Lactobacillus helveticus, Lactobacillus amylovorus, Lactobacillus hamsteri, L. johnsonii, L. gasseri and Lactobacillus amylolyticus. The name Lactobacillus fornicalis sp. nov. is proposed for strains TV 1010 (DSM 13172), TG 1013, TV 1018 ${ }^{\top}$ and TV

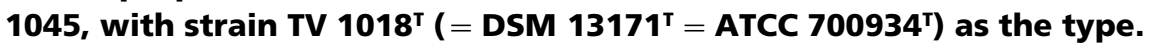

Keywords: Lactobacillus fornicalis sp. nov., human vagina, taxonomy, phylogeny, lactic acid bacteria

\section{INTRODUCTION}

The genus Lactobacillus is divided into three groups based on the fermentative abilities of the species (Kandler \& Weiss, 1986). Group I, the obligately homofermentative species, degrade hexoses almost completely to lactic acid and do not ferment pentoses or gluconate. Species of group II are facultatively heterofermentative and produce acetic acid, ethanol and formic acid under glucose limitation, in addition to lactic acid. Pentoses are usually fermented. Group III contains the obligately heterofermentative lacto-

\footnotetext{
Abbreviations: RAPD, randomly amplified polymorphic DNA; UPGMA, unweighted pair group method with arithmetic averages.

The GenBank accession number for the 16S rRNA gene sequence of strain TV $1018^{\top}$ is $\mathrm{Y} 18654$.
}

bacilli which ferment hexoses to lactic acid, acetic acid, ethanol and carbon dioxide. Pentoses are fermented to lactic acid and acetic acid.

Group I contains 21 species, divided into two subgroups based on DNA-DNA hybridization (Kandler \& Weiss, 1986). Subgroup 1 includes Lactobacillus delbrueckii (the type species of the genus) and Lactobacillus jensenii (Kandler \& Weiss, 1986). Subgroup 2 is represented by Lactobacillus acidophilus, Lactobacillus amylophilus, Lactobacillus farciminis, Lactobacillus kefiranofaciens, Lactobacillus vitulinus, Lactobacillus intestinalis, Lactobacillus uli (Pot et al., 1994) and the 'Lactobacillus casei/Pediococcus group of lactobacilli', viz. Lactobacillus aviarius, Lactobacillus animalis, Lactobacillus salivarius, Lactobacillus mali, Lactobacillus ruminis and Lactobacillus sharpeae (Collins et al., 1991). The L. acidophilus group was 
Table 1. Genotypic relatedness among L. johnsonii, L. acidophilus, L. gallinarum, L. crispatus, L. gasseri, L. jensenii and L. fornicalis sp. nov.

Strains printed in bold were selected for RAPD-PCR analysis.

\begin{tabular}{|c|c|c|}
\hline Strain* & Protein cluster $\dagger$ & RAPD-PCR cluster \\
\hline $\begin{array}{l}\text { L. johnsonii } \\
\text { TV 1016, TV 1035, TG 1038, } \\
\text { TG 1016, NCIMB } \mathbf{7 0 2 2 4 1}^{\mathrm{T}} \text {, } \\
\text { TV 1005, TV 1048, TG } 1027\end{array}$ & I & V \\
\hline $\begin{array}{l}\text { L. acidophilus } \\
\text { TG 1025 } \\
\text { TV 1001, ATCC } 4356^{\mathrm{T}} \text {, } \\
{\text { NCIMB } \mathbf{7 0 1 7 4 8}^{\mathrm{T}}}\end{array}$ & $\begin{array}{l}\text { I } \\
\text { II }\end{array}$ & $\begin{array}{l}\text { IV } \\
\text { IV }\end{array}$ \\
\hline $\begin{array}{l}\text { L. gallinarum } \\
\text { NCIMB 702235 }{ }^{\mathrm{T}} \text {, TV } 1006\end{array}$ & III & III \\
\hline $\begin{array}{l}\text { L. crispatus } \\
\text { TG 1010, NCIMB 45704, } \\
\text { NCIMB 702752 }{ }^{\mathrm{T}} \text {, NCIMB } \\
\text { 45705, TG } 1006\end{array}$ & IV & $\mathrm{NC} \S$ \\
\hline $\begin{array}{l}\text { L. gasseri } \\
\text { DSM 20077 }{ }^{\mathrm{T}}, \mathrm{TG} 1034, \mathbf{T V} \\
\mathbf{1 0 1 3}\end{array}$ & V & VI \\
\hline $\begin{array}{l}\text { L. jensenii } \\
\text { DSM 20557 }{ }^{\mathrm{T}} \text {, TV 1036, TV } \\
\quad \mathbf{1 0 4 4}, \mathrm{TG} 1030\end{array}$ & V & II \\
\hline $\begin{array}{l}\text { L. fornicalis sp. nov. } \\
\text { TV 1010, TG 1013, TV } 1018^{\mathrm{T}} \text {, } \\
\text { TV } 1045\end{array}$ & VI & I \\
\hline
\end{tabular}

* TV and TG, strains isolated from patients who attended pre- and post-natal clinics, respectively.

$\dagger$ From Fig. 1.

† From Fig. 2.

$\S \mathrm{NC}$, Did not cluster with the other strains.

later divided into six genotypic groups based on DNA-DNA hybridization, with the species L. acidophilus in group A1 (Fujisawa et al., 1992). Groups A2, A3 and A4 contain Lactobacillus crispatus (Cato et al., 1983), Lactobacillus amylovorus and Lactobacillus gallinarum (Fujisawa et al., 1992), respectively. Groups B1 and B2 include Lactobacillus gasseri (Lauer \& Kandler, 1980) and Lactobacillus johnsonii (Fujisawa et al., 1992), respectively.

In humans, as many as $10^{7}-10^{8}$ Lactobacillus spp. $\mathrm{ml}^{-1}$ have been reported in vaginal fluid (RedondoLopez et al., 1990). The obligately homofermentative species thus far isolated include $L$. acidophilus, $L$. crispatus and L. jensenii; the facultatively heterofermentative species Lactobacillus plantarum and $L$. case $i$; and the obligately heterofermentative species Lactobacillus brevis and Lactobacillus fermentum (Fernandes et al., 1987; Giorgi et al., 1987).

In this study, we have investigated the relatedness among 21 strains of obligately homofermentative (group I) Lactobacillus spp. isolated from the posterior fornix fluid of the vagina of healthy pre- and post-natal patients and representative strains of L. acidophilus, L. crispatus, L. jensenii, L. gallinarum, L. gasseri and L. johnsonii using both phenotypic and genotypic methods. Based on the results of this polyphasic taxonomic study we propose a new species, Lactobacillus fornicalis.

\section{METHODS}

Bacterial strains and growth conditions. Twenty-one strains of lactic acid bacteria were isolated from the posterior fornix secretions of the vagina of 18 healthy patients who attended the pre- and post-natal clinics at the Tygerberg Hospital in Tygerberg, South Africa (Table 1). The swabs collected from the patients were immersed in $1 \mathrm{ml}$ sterile physiological salt (Univar) and immediately spread-plated (100 $\mu$ l) onto MRS agar (Biolab). Colonies were selected from the plates after $2 \mathrm{~d}$ incubation at $37^{\circ} \mathrm{C}$. Reference strains were obtained from the National Collection of Industrial and Marine Bacteria (NCIMB), American Type Culture Collection (ATCC), Deutsche Sammlung von Mikroorganismen und Zellkulturen (DSMZ) and the Culture Collection, University 

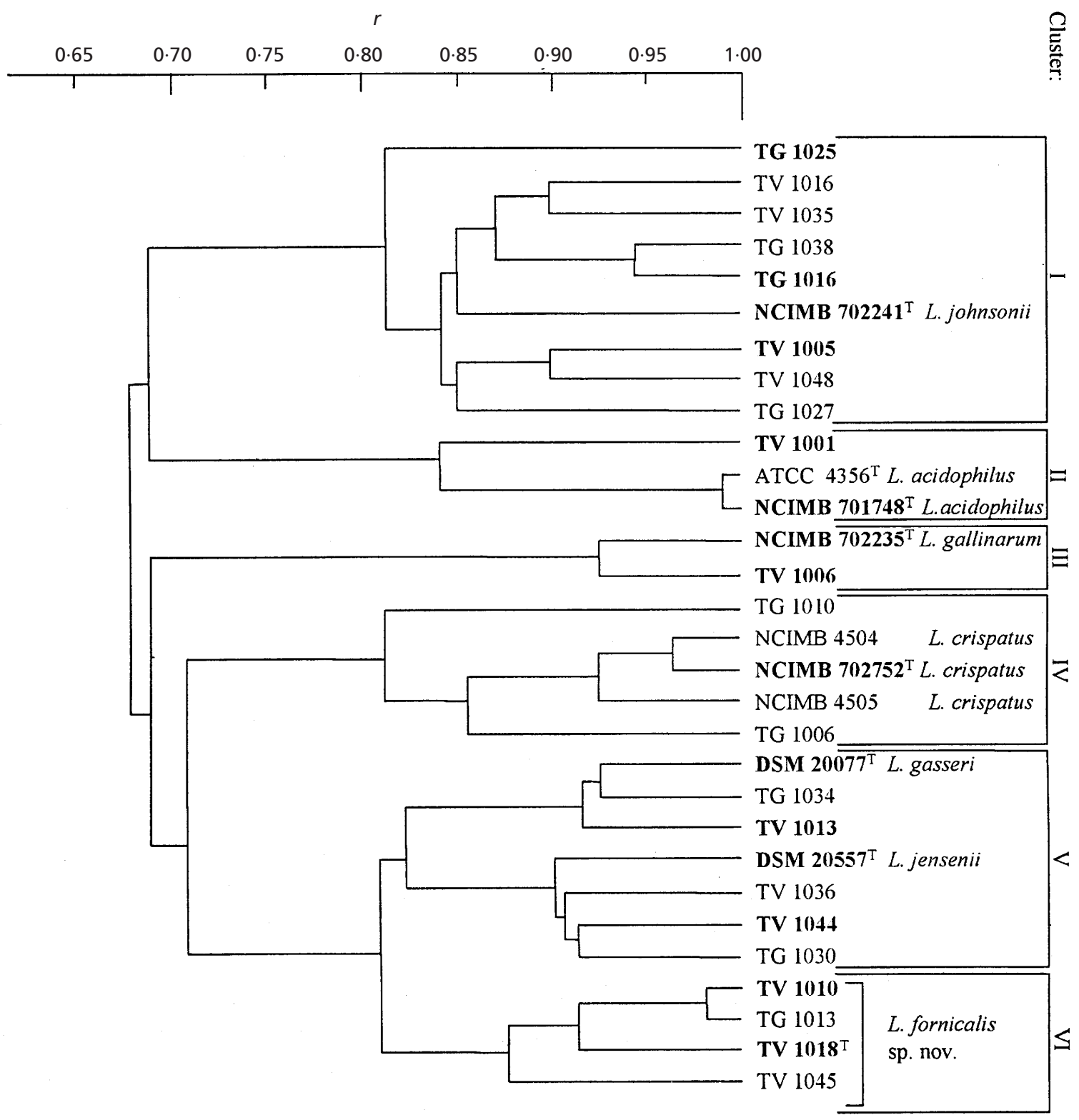

Fig. 1. Dendrogram showing the clustering of L. johnsonii, L. acidophilus, L. gallinarum, L. crispatus, L. gasseri, L. jensenii and $L$. fornicalis sp. nov. obtained by numerical analysis of total soluble cell protein patterns. Clustering was by UPGMA.

of Göteborg, Sweden (CCUG). All strains were cultured in MRS broth (Biolab) at $37^{\circ} \mathrm{C}$.

Numerical analysis of total soluble cell protein patterns. Cultures were grown in MRS broth (Biolab) for $24 \mathrm{~h}$ at $37^{\circ} \mathrm{C}$. Protein isolation and gel electrophoresis were performed as described by Vauterin et al. (1993). The Gelcompar computer program (version 4.0) of Applied Maths was used to analyse the protein banding patterns. The program recorded the normalized electrophoretic patterns of the densitometric traces, grouped the isolates by the Pearson product moment correlation coefficient $(r)$ and performed UPGMA (unweighted pair group method with arithmetic averages) cluster analysis of the protein bands.

Numerical analysis of randomly amplified polymorphic DNA (RAPD)-PCR profiles. Strains representative of each subgroup within a cluster were selected (Table 1). The DNA of these strains was isolated according to the method of Dellaglio et al. (1973). Three single primers [TGGGCGTCAA (OPL02), ACGCAGGCAC (OPL-05) and ACGATGAGCC (OPL-11)] were used and the DNA amplification performed according to the methods described by Van Reenen \& Dicks (1996). Lambda DNA, digested with EcoRI and HindIII (Boehringer Mannheim), was used as molecular mass marker. Numerical analysis of RAPD-PCR profiles was done using the CLUSTER program of SAS Institute, according to the methods described by Van Reenen \& Dicks (1996).

Determination of 16S rRNA gene sequences and phylogenetic analyses. A large fragment of the $16 \mathrm{~S}$ rRNA gene was amplified by PCR by using universal primers $\mathrm{pA}$ (5'-AGAGTTTGATCCTGGCTCAG; positions 8-27, Escherichia coli numbering) and $\mathrm{pH}^{*}$ (5'-AAGGAGGTGATCCAGCCGCA; positions 1541-1522). The PCR pro- 
ducts were purified by using a Prep-A-Gene kit (Bio-Rad) according to the manufacturer's instructions and were sequenced by using a Taq DyeDeoxy Terminator Cycle Sequencing kit (Applied Biosystems) and a model 373A automatic sequencer (Applied Biosystems). The closest known relatives of the new isolates were determined by performing sequence database searches and the sequences of closely related strains were retrieved from GenBank or Ribosomal Database Project libraries. Sequences were aligned by using the program PILEUP (Devereux et al., 1984) and the alignment was corrected manually. Distance matrices were produced by using the programs PRETTY and DNADIST (using the Kimura-2 correction parameter) (Felsenstein, 1989). A phylogenetic tree was constructed according to the neighbour-joining method with the program NEIGHBOR (Felsenstein, 1989). The statistical significance of the groups obtained was assessed by bootstrapping (500 replicates) by using the programs DNABOOT, DNADIST, NEIGHBOR and CONSENSE (Felsenstein, 1989).

DNA base composition. DNA was isolated and purified by using the technique described by Dicks et al. (1990). The $\mathrm{G}+\mathrm{C}$ content was calculated by using the method of Marmur \& Doty (1962).

Biochemical and physiological tests. The biochemical and physiological characteristics of all strains were determined by using the methods described by Sharpe (1979). Carbohydrate fermentation characteristics of all strains were determined by using the API 50CHL system. Results were recorded after $48 \mathrm{~h}$ at $37^{\circ} \mathrm{C}$.

\section{RESULTS AND DISCUSSION}

Twenty-one strains isolated from the posterior fornix fluid of the human vagina grouped into six protein profile clusters at $r \geqslant 0 \cdot 82$, well separated from each other at $r \geqslant 0.67$ (Fig. 1).

Eight strains of the vaginal isolates grouped with the type strain of L. johnsonii (NCIMB $702241^{\mathrm{T}}$ ) in cluster I at $r \geqslant 0.82$. The overall protein profile of strain $\mathrm{TG}$ 1025 was, however, different from the other strains in cluster I, as also indicated by its lower clustering at $r \geqslant$ $0 \cdot 82$. Strain TG 1025 is thus considered an intruder in cluster I, a phenomenon which has been described by Kersters \& De Ley (1975). One strain formed a tight cluster with the type strain of L. acidophilus (ATCC $4356^{\mathrm{T}}$, NCIMB $701748^{\mathrm{T}}$ ) in cluster II at $r \geqslant 0 \cdot 84$, one strain linked with the type strain of $L$. gallinarum (NCIMB $702235^{\mathrm{T}}$ ) in cluster III at $r \geqslant 0.93$, and two strains grouped with L. crispatus in cluster IV at $r \geqslant$ $0 \cdot 82$ (Fig. 1). These groupings were confirmed by numerical analysis of RAPD-PCR banding patterns (Fig. 2). Strains within each protein profile cluster displayed similar DNA profiles, whereas strains from different clusters displayed unique banding patterns (Table 1). Similar results were recorded in one of our previous studies on L. acidophilus, L. crispatus, $L$. amylovorus, L. gallinarum, L. gasseri and L. johnsonii (Du Plessis \& Dicks, 1995). The RAPD-PCR profile of strain TG 1025 was, however, different from the other three strains of $L$. johnsonii in cluster I, but similar to the profiles recorded for L. acidophilus (Fig. 2). Based on these results, strains TV 1016, TV 1035, TG 1038, TG 1016, TV 1005, TV 1048 and TG 1027 (cluster I, Fig. 1) are classified as L. johnsonii, whereas strains TG 1025 (cluster I, Fig. 1) and TV 1001 (cluster II, Fig. 1) are considered members of L. acidophilus and strain TV 1006 (cluster III, Fig. 1) a strain of L. gallinarum. Strains TG 1010 and TG 1006 (cluster IV, Fig. 1) are classified as L. crispatus.

Five strains (TG 1034, TV 1013, TV 1036, TV 1044 and TG 1030) grouped with the type strains of $L$. gasseri (DSM 20077 ${ }^{\mathrm{T}}$ ) and L. jensenii (DSM 20557 $)$ at

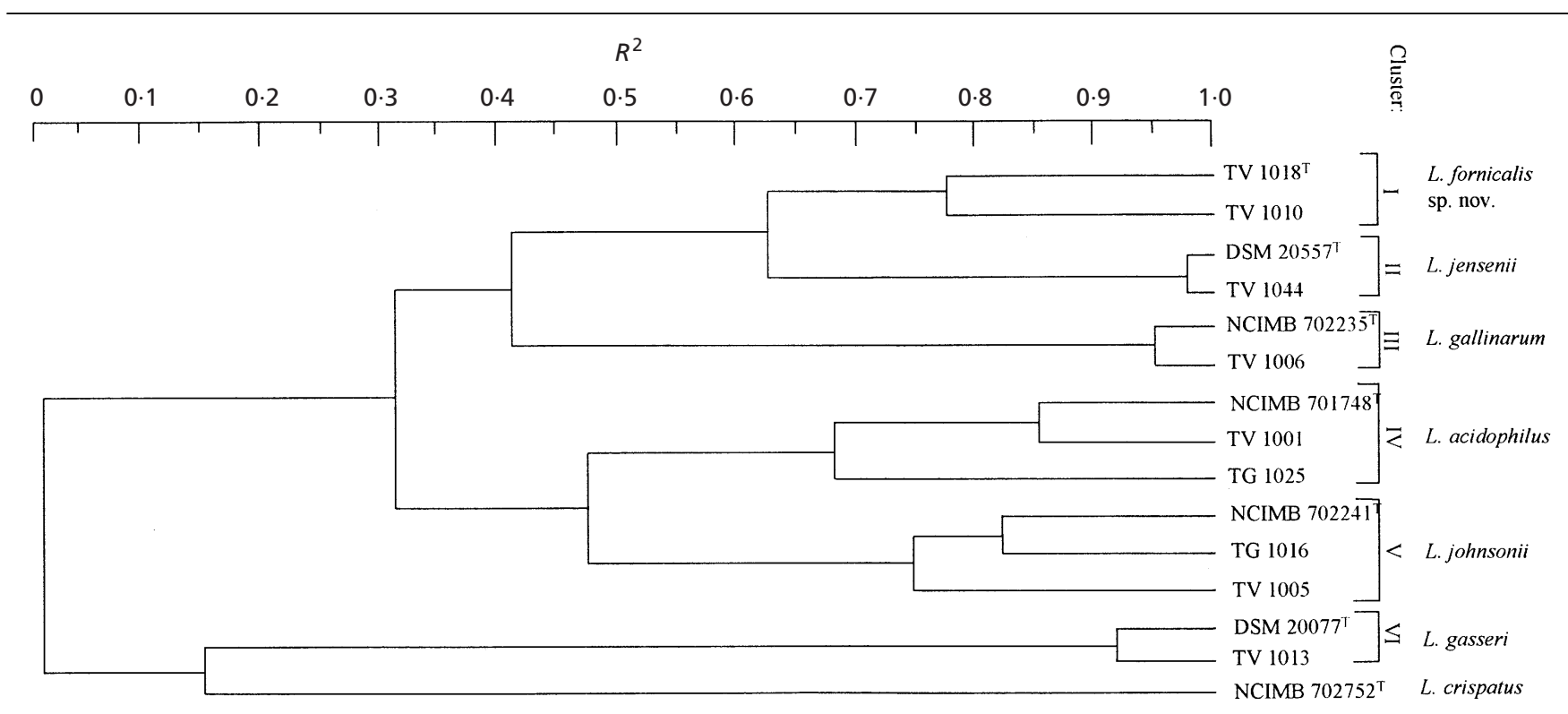

Fig. 2. Dendrogram showing the clustering of L. fornicalis sp. nov., L. jensenii, L. gallinarum, L. acidophilus, L. johnsonii, $L$. gasseri and $L$. crispatus obtained by numerical analysis of RAPD-PCR profiles. Clustering was by normalized average linkage analysis. Distances between clusters are expressed in $R^{2}$ values. 


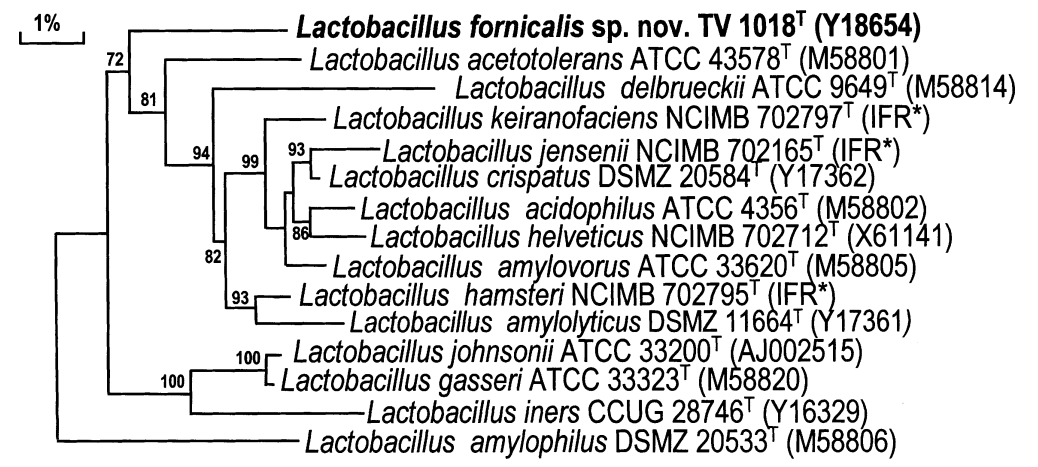

Fig. 3. Unrooted tree showing the phylogenetic relationships of $L$. fornicalis $\mathrm{sp}$. nov. and closely related lactic acid bacteria. The tree constructed using the neighbourjoining method was based on a comparison of approximately 1320 nucleotides. Bootstrap values, expressed as a percentage of 500 replications, are given at branching points. Asterisks indicate sequences from the Institute of Food Research (Reading, UK) database.

Table 2. Differential carbohydrate fermentation reactions among strains of $L$. johnsonii, L. acidophilus, L. gallinarum, L. crispatus, L. gasseri, L. jensenii and L. fornicalis sp. nov.

,$+ 90 \%$ or more of strains positive;,$- 90 \%$ or more of strains negative; d, $11-98 \%$ of strains positive; ND, not determined. Data for L. johnsonii, L. acidophilus, L. gallinarum, L. crispatus and L. gasseri are from Fujisawa et al. (1992); data for L. jensenii are from Kandler \& Weiss (1986). All strains fermented amygdalin, cellobiose, fructose, galactose, glucose, maltose, mannose, salicin and sucrose, and hydrolysed aesculin. None of the strains fermented arabinose, rhamnose and xylose. All strains produced DL-lactic acid from glucose, except $L$. jensenii which produced the D-isomer.

\begin{tabular}{|c|c|c|c|c|c|c|c|}
\hline Carbohydrate & L. johnsonii & L. acidophilus & L. gallinarum & L. crispatus & L. gasseri & L. jensenii & $\begin{array}{l}\text { L. fornicalis } \\
\text { sp. nov. }\end{array}$ \\
\hline Dextrin & $\mathrm{d}$ & - & + & $\mathrm{d}$ & + & ND & $\mathrm{ND}$ \\
\hline Lactose & d & + & $\mathrm{d}$ & $\mathrm{d}$ & + & - & - \\
\hline Mannitol & - & - & - & $\mathrm{d}$ & - & $\mathrm{d}$ & + \\
\hline Melibiose & $\mathrm{d}$ & - & + & $\mathrm{d}$ & $\mathrm{d}$ & - & - \\
\hline Melezitose & - & - & - & - & - & - & + \\
\hline Raffinose & $\mathrm{d}$ & $\mathrm{d}$ & + & + & - & - & - \\
\hline Ribose & - & - & - & $\mathrm{d}$ & - & - & + \\
\hline Sorbitol & - & - & - & - & - & - & + \\
\hline Starch & $\mathrm{d}$ & - & $\mathrm{d}$ & $\mathrm{d}$ & $\mathrm{d}$ & ND & - \\
\hline Trehalose & $\mathrm{d}$ & + & - & $\mathrm{d}$ & + & + & + \\
\hline
\end{tabular}

$r \geqslant 0.83$ in cluster $\mathrm{V}$ (Fig. 1). Two of the strains (TG 1034 and TV 1013) formed a tight grouping with $L$. gasseri DSM 20077 ${ }^{\mathrm{T}}$, whereas strains TV 1036, TV 1044 and TG 1030 linked closer to L. jensenii DSM $20557^{\mathrm{T}}$. These groupings were confirmed by numerical analyses of the RAPD-PCR profiles. The RAPD-PCR profile of strain TV 1013 was almost identical to that of L. gasseri DSM $20077^{\mathrm{T}}$, as shown by the high similarity value $\left(R^{2} \geqslant 0.92\right)$ recorded between the two strains (Fig. 2). On the other hand, strain TV 1044 shared a high DNA similarity with $L$. jensenii DSM $20557^{\mathrm{T}}$, as revealed by the high correlation $\left(R^{2} \geqslant 0.98\right)$ recorded in their RAPD-PCR banding patterns (Fig. 2). These findings suggest that numerical analysis of RAPDPCR banding patterns are more reliable than numerical analysis of total soluble cell protein patterns in differentiating strains of $L$. gasseri and $L$. jensenii. Additional strains will have to be studied to confirm this suggestion.

Four strains (TV 1010, TG 1013, TV $1018^{\mathrm{T}}$ and TV 1045) were phenotypically different from any of the species included in this study and formed a tight phenotypic group at $r \geqslant 0.87$ (cluster VI, Fig. 1). The RAPD-PCR profiles of two representative strains from this cluster (TV $1018^{\mathrm{T}}$ and TV 1010) were found to be very similar, as shown by the high correlation value $\left(R^{2}\right.$ $\geqslant 0.78$ ) recorded between the two strains (Fig. 2). To investigate the phylogenetic position of this group, the almost complete $16 \mathrm{~S}$ rRNA gene sequence $(>1400$ nucleotides) of strain TV $1018^{\mathrm{T}}$ was determined, and subjected to a comparative analysis. Sequence database searches (data not shown) revealed the bacterium was closely related to the L. delbrueckii group of organisms (rRNA group I; see Collins et al., 1991) with other lactobacilli more distantly related. A tree depicting the phylogenetic affinities of strain TV $1018^{\mathrm{T}}$ is shown in Fig. 3. It was evident from both sequence divergence values of $>5 \%$ with other members of the L. delbrueckii rRNA cluster and the treeing analysis that the unidentified bacterium represents a hitherto unknown Lactobacillus species. The 16S rRNA gene sequence of a second isolate, TG 1013, of the novel vaginal bacterium was also sequenced $(>1400$ nucleotides) and showed $99.9 \%$ sequence similarity with strain TV $1018^{\mathrm{T}}$, thereby confirming their genotypic 
identity. Thus, based on phenotypic and phylogenetic findings, we propose the name Lactobacillus fornicalis sp. nov. for strains TV 1010, TG 1013, TV $1018^{\mathrm{T}}$ and TV 1045 , with strain TV $1018^{\mathrm{T}}$ as the type. A full description of L. fornicalis is given below.

\section{Description of Lactobacillus fornicalis sp. nov.}

Lactobacillus fornicalis (for.nic.a'lis. L. gen. n. fornicalis of the posterior fornix).

Gram-positive rods. Non-motile, non-sporulating, catalase-negative and oxidase-negative. Colonies on MRS agar are round, smooth, white and approximately $1 \mathrm{~mm}$ in diameter. Growth occurs at temperatures between 20 and $40{ }^{\circ} \mathrm{C}$ on MRS agar, with the optimum temperature between 35 and $37^{\circ} \mathrm{C}$. Facultatively anaerobic, but grows well on the surface of MRS agar when not incubated under microaerophilic conditions. Obligately homofermentative, with no gas production from glucose or gluconate. $\mathrm{D}(-)$ - and L-lactic acid are produced from glucose. Aesculin is hydrolysed. Voges-Proskauer-negative. Indole is not formed and nitrates are not reduced. Polysaccharides are not produced from sucrose. Lactobacillus fornicalis is distinguished from L. johnsonii, L. acidophilus, L. gallinarum, L. crispatus, L. gasseri and $L$. jensenii on the basis of a few carbohydrate fermentation reactions (Table 2). Acid is produced from amygdalin, cellobiose, fructose, galactose, glucose, maltose, mannose, mannitol, melezitose, ribose, salicin, sorbitol, sucrose and trehalose. Arabinose, lactose, melibiose, raffinose, rhamnose, starch and xylose are not fermented. The $\mathrm{G}+\mathrm{C}$ content of the type strain is $37 \mathrm{~mol} \%$ (as determined by the thermal denaturation method). Isolated from the posterior fornix fluid of the human vagina. The type strain is TV $1018^{\mathrm{T}}\left(=\mathrm{DSM} 13171^{\mathrm{T}}=\right.$ ATCC $\left.700934^{\mathrm{T}}\right)$.

\section{ACKNOWLEDGEMENTS}

We are grateful to the British Council and the Industrial Development Corporation (South Africa) for financial assistance.

\section{REFERENCES}

Cato, E. P., Moore, W. E. C. \& Johnson, J. L. (1983). Synonymy of strains of "Lactobacillus acidophilus" group A2 (Johnson et al. 1980) with the type strain of Lactobacillus crispatus (Brygoo and Aladame 1953) Moore and Holdeman 1970. Int J Syst Bacteriol 33, 426-428.

Collins, M. D., Rodrigues, U. M., Ash, C., Aguirre, M., Farrow, J. A. E., Martinez-Murcia, A., Phillips, B. A., Williams, A. M. \& Wallbanks, S. (1991). Phylogenetic analysis of the genus Lactobacillus and related lactic acid bacteria as determined by reverse transcriptase sequencing of $16 \mathrm{~S}$ rRNA. FEMS Microbiol Lett 77, 5-12.

Dellaglio, F., Bottazi, V. \& Trovatelli, L. D. (1973). Deoxyribonucleic acid homology and base composition in some thermophilic lactobacilli. J Gen Microbiol 74, 289-297.

Devereux, J., Haeberli, P. \& Smithies, O. (1984). A comprehensive set of sequence analysis programs for the VAX. Nucleic Acids Res 12, 387-395.

Dicks, L. M. T., Van Vuuren, H. J. J. \& Dellaglio, F. (1990). Taxonomy of Leuconostoc species, particularly Leuconostoc oenos, as revealed by numerical analysis of total soluble cell protein patterns, DNA base compositions, and DNA-DNA hybridizations. Int J Syst Bacteriol 40, 83-91.

Du Plessis, E. M. \& Dicks, L. M. T. (1995). Evaluation of random amplified polymorphic DNA (RAPD)-PCR as a method to differentiate Lactobacillus acidophiluis, Lactobacillus crispatus, Lactobacillus amylovorus, Lactobacillus gallinarum, Lactobacillus gasseri, and Lactobacillus johnsonii. Curr Microbiol 31, 114-118.

Felsenstein, J. (1989). PHYLIP - phylogeny inference package (version 3.2). Cladistics 5, 164-166.

Fernandes, C. F., Shahani, K. M. \& Amer, M. A. (1987). Therapeutic role of dietary lactobacilli and lactobacilli fermented dairy products. FEMS Microbiol Rev 46, 343-356.

Fujisawa, T., Benno, Y., Yaeshima, T. \& Mitsuoka, T. (1992). Taxonomic study of the Lactobacillus acidophilus group, with recognition of Lactobacillus gallinarum sp. nov. and Lactobacillus johnsonii sp. nov. and synonomy of Lactobacillus acidophilus group A3 (Johnson et al. 1980) with the type strain of Lactobacillus amylovorus (Nakamura 1981). Int J Syst Bacteriol 42, 487-491.

Giorgi, A., Torriani, S., Dellaglio, F., Bo, G., Stola, G. \& Bernuzzi, L. (1987). Identification of vaginal lactobacilli from asymptomatic women. Microbiologica 10, 377-384.

Kandler, O. \& Weiss, N. (1986). Genus Lactobacillus Beijerinck 1901, 212 $\mathrm{AL}$. In Bergey's Manual of Systematic Bacteriology, vol. 2, pp. 1209-1234. Edited by P. H. A. Sneath, N. S. Mair, M. E. Sharpe \& J. G. Holt. Baltimore: Williams \& Wilkins.

Kersters, K. \& De Ley, J. (1975). Identification and grouping of bacteria by numerical analysis of their electrophoretic protein patterns. J Gen Microbiol 87, 333-342.

Lauer, E. \& Kandler, O. (1980). Lactobacillus gasseri sp. nov., a new species of the subgenus Thermobacterium. Zentbl Bakteriol Parasitenkd Infektkrankh Hyg Abt I Orig C1, 75-78.

Marmur, J. \& Doty, P. (1962). Determination of the base composition of deoxyribonucleic acid from its thermal denaturation temperature. J Mol Biol 5, 109-118.

Pot, B., Ludwig, W., Kersters, K. \& Schleifer, K.-H. (1994). Taxonomy of lactic acid bacteria. In Bacteriocins of Lactic Acid Bacteria: Microbiology, Genetics and Applications, pp. 13-90. Edited by L. De Vuyst \& E. J. Vandamme. London: Blackie Academic \& Professional.

Redondo-Lopez, V., Cook, R. L. \& Sobel, J. D. (1990). Emerging role of lactobacilli in the control and maintenance of the vaginal bacterial microflora. Rev Infect Dis 12, 856-872.

Sharpe, M. E. (1979). Identification of lactic acid bacteria. In Identification Methods for Microbiologists (Technical Series 14), pp. 233-259. Edited by F. A. Skinner \& D. W. Lovelock. London: Academic Press.

Van Reenen, C. A. \& Dicks, L. M. T. (1996). Evaluation of numerical analysis of random amplified polymorphic DNA (RAPD)-PCR as a method to differentiate Lactobacillus plantarum and Lactobacillus pentosus. Curr Microbiol 32, 183-187.

Vauterin, L., Swings, J. \& Kersters, K. (1993). Protein electrophoresis and classification. In Handbook of New Bacterial Systematics, pp. 251-280. Edited by M. Goodfellow \& A. G. O'Donnell. London: Academic Press. 